\title{
Truth and Denomination Discrimination of Notes using Surface Properties Evaluated by Scanning with Optical Fiber Feeler
}

\author{
Jun-ya Takayama Non-member (Tokyo Institute of Technology, takayama@ctrl.titech.ac.jp) \\ Shinji Ohyama Member (Tokyo Institute of Technology, sohyama@ctrl.titech.ac.jp)
}

Akira Kobayashi Member (National Inst. for Acad. Degrees and Univ. Evaluation, akobayas@niad.ac.jp)

Keywords: surface properties, optical fiber feeler, stick-slip component

In this paper, a novel method is proposed to discriminate the truth and denomination of notes. In order to perform a reliable and useful discrimination of notes, the use of both inherent and genuine properties is effective. When the surface of the note is scanned with an optical fiber feeler, peculiar vibrating motions of the fiber feeler tip occur with various surface properties and its motion is measured as a waveform, as shown in Fig.1. By analyzing this, two components correlated to each different surface property can be extracted independently: The first is the low-frequency component, and the second is a stick-slip component.

The low-frequency component is derived from the variable density property of the surface print pattern. As shown on a left-side of Fig.2, the low-frequency component of the measured waveform is directly correlated to the variabledensity of an example print pattern. Consequently, the lowfrequency component is used to discriminate the surface print pattern, i.e. the denomination. Essentially, the zero-cross points $D_{n}$ shown on the right-side of Fig.2 are compared with a data-base of the print color changing points of genuine notes and a difference between them is evaluated.

In contrast, the stick-slip component is derived from the roughness property, as shown in Fig.3. Since an undulation of the intaglio print, which is inherent in only genuine notes, causes the stick-slip, truth can be discriminated by evaluat-
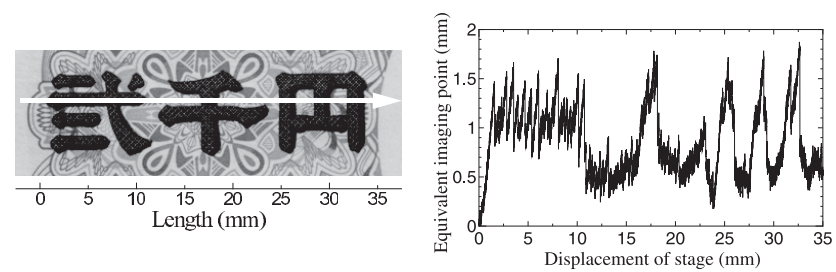

Fig. 1. Measured waveform of the feeler tip motion
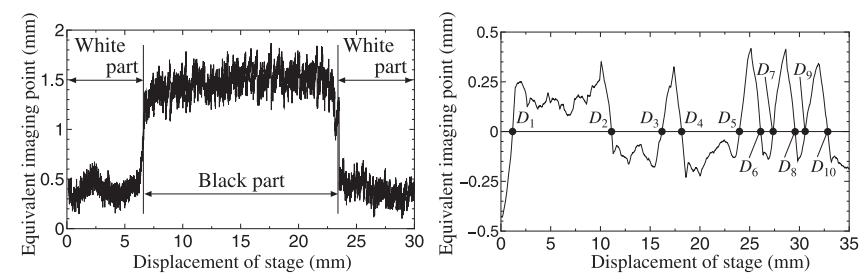

Fig. 2. Waveform derived from the print pattern and low-frequency component for a 2,000Yen note ing whether the stick-slip component exists. Indexes for the existence of the stick-slip components are newly proposed by focusing on features of the measured waveforms accompanied by stick-phenomenon whose gradient corresponds to 45 degrees and whose amplitude is larger than that of other components. Thus, the amplitude index of the stick-slip elements $L_{n}$ and the gradient index of the stick-phenomenon $\theta_{n}$ are introduced.

In addition, the existence frequency of the stick-slip components depends on whether the measurement of the fiber feeler motion is carried out on the intaglio print part. The relationships between $L_{n}$ and $\theta_{n}$ are shown in Fig.4; the distribution of the print part is clearly different from that of the non-print part with the genuine notes while it is nearly identical to that of a counterfeit notes. From these results, truth discrimination can be improved by selecting the print and non-print parts based on the print pattern data and then comparing and evaluating the indexes for each part.

Finally, an improved discrimination method is constructed by integrating the proposed two surface property extraction methods. Perfect truth and denomination discrimination performance has been confirmed from experimental results for both circulated and counterfeit notes.
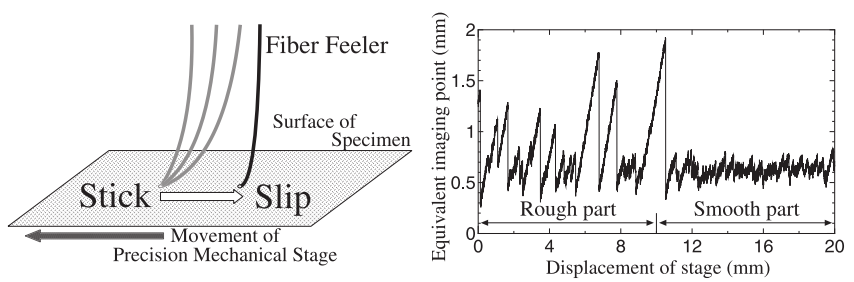

Fig. 3. Schematic view of the stick-slip phenomenon of the feeler and its measured waveform derived from roughness
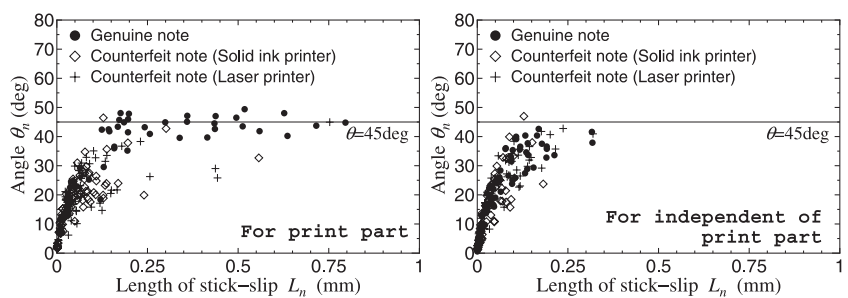

Fig. 4. Relationships between $L_{n}$ and $\theta_{n}$ for the extracted stick-slip component according to the print part and independent of the print part 


\title{
光ファイバ触針走査による表面性状情報を利用した 紙幣の真贋・金種判別
}

\author{
非会員 高山 潤也* 正 員 大山 真司* \\ 正員 小林涁**
}

Truth and Denomination Discrimination of Notes using Surface Properties
Evaluated by Scanning with Optical Fiber Feeler
Jun-ya Takayama*, Non-member, Shinji Ohyama*, Member, Akira Kobayashi**, Member

It is effective to use both inherent and genuine properties for a reliable discrimination of notes. When the surface of the note is scanned with the tip of an optical fiber feeler, peculiar vibration waveform correlated to various surface properties is measured. In this paper, a novel method to discriminate the truth and denomination of notes is proposed by analyzing this. Two matters can be evaluated independently. The first is the roughness property extracted from the stick-slip component with an undulation of the intaglio print, which is inherent in only genuine notes. Truth can be discriminated by evaluating whether the stick-slip component exists on print part of vibration waveforms. The second is the variable-density property extracted from the low-frequency component with a print pattern. Denomination can be discriminated by comparing the variable-density pattern with the data-base of it for each denomination of notes. An improved discrimination method is constructed by integrating the proposed two property evaluation methods, and its effectiveness has been confirmed from experimental results for both circulated and counterfeit notes.

キーワード：表面性状，光ファイバ触針，ステイックスリップ成分

Keywords: surface properties, optical fiber feeler, stick-slip component

\section{1. 緒言}

ここ数年の間に日本国内でも紙幣偽造事件が急激に増加 してきている(1)。これは, 自動販売機を中心に透過光量や 磁気を利用した簡易的な金種・真贋判別技術が広く採用さ れていることに加え，プリンタやスキャナなどによるデジ タル画像処理技術が高性能化し, 個人にも偽造が比較的容 易になったことがその理由であるといわれている。

簡易的な真贋判別技術としては，透かしや印章を紫外線 で浮かび上がらせる技術 (2) や微細な周期的印刷模様に起因 するモアレ現象を利用する技術 (3) を利用した製品が既に市

\footnotetext{
* 東京工業大学 大学院理工学研究科

干 152-8552 目黒区大岡山 2-12-1

Graduate school of Science and Engineering, Tokyo Institute of Technology

Ookyama 2-12-1 Meguro-ku 152-8552

** 大学評価 · 学位授与機構

干 187-8587 小平市学園西町 1-29-1

National Institution for Academic Degrees and University Evaluation

Gakuennishicho 1-29-1 Kodaira-city 187-8587
}

販されているが，判別に人の目を必要とするなど自動判別 機への展開は容易とはいえない。近年では, インクジェット プリンタで印刷された贋券に残った紙送り機構による紙面 スパイク跡の特性を空間周波数解析により抽出して贋券を 判別する方法 ${ }^{(4)}$ や, デジタルカメラ撮影画像に対し写真製 版用フィルタを通し真券との微妙な印刷色の違いを見極め る方法(5) なども提案されているが，いずれも紙幣に固有な 性状を必ずしも有効に活用しておらず，決定的な方法とは 成り得ていない。現行紙幣 (E券) には, 従来からの透かし などに加えて, 深凹版印刷, パールインク, ホログラムをは じめとする新技術によって紙幣に固有な性状が増え, それ らを複合的に利用した方法によって判別を実現することが 望ましい。特に深凹版印刷の導入により, 従来紙幣 (D 券) に比較して印刷面の凹凸が際立っていることは特徵的であ り，真贋判別へ積極的に利用すべきである。

一方，我々は布の表面を触針でなぞったときの走査波形 から，その手触り感あるいは表面性状を評価しようとする 試みを続けてきた。ステイックスリップ現象に起因した触針 先端の微小な振動変位成分の有無 · 大きさが表面の凹凸度 合いと相関をもつことが明らかになり ${ }^{(6)}(7)$, ここで得られ 
た知見が紙幣判別にも応用できる可能性は高い。そこで本 研究の目的は，凹版印刷による凹凸・摩擦係数変化や印刷 模様など紙幣に固有かつ特徴的な表面性状に着目して，触 針走査波形から獲得される性状を複合的に利用し，信頼性 を高めた真贋・金種判別方法を構築することにある。

本論文では，はじめに光ファイバを触針とした走査装置 の構成を示し，走査波形に現れる 2 つ特徽成分から試料 表面の凹凸・摩擦係数および印刷模様に関する性状情報が 獲得できることを明らかにする。次いで各特徴成分を独立 に抽出・解析する方法を提案し，各成分と相関をもつ性状 情報が指標值を利用して個別に評価できることを説明する。 さらに 2 つの解析方法を複合的に組み合わせ，獲得される 性状情報を効果的に利用して信頼性を高めた真贋 ・金種判 別方法を実現する。最後に市中に流通する紙幣に提案方法 を適用し，実験的に判別性能を検証することによって，そ の有効性を明らかにする。

\section{2． 光ファイバ触針走査による表面性状情報の獲得}

$\langle\mathbf{2} \cdot \mathbf{1}\rangle$ 光ファイバ触針走査装置の構成 光ファイバ触 針走査装置の構成とその写真を Fig.1 に示す。試料紙幣は 精密移動台上に固定し，レーザダイオードによって先端を 発光させた光ファイバ触針が表面に押し付けられている。 触針と共通の台座上にはPSD センサが固定され，PSD と 触針の間に凸レンズを配置して結像系を構成している。

光ファイバには，弾性域が比較的広いプラスチック製の 三菱レイヨン社製 CK-40 を選定した。その主要な仕様に ついては Table 1 にまとめる。光ファイバ触針の先端面は 垂直に切断した上で研磨処理を施し，触針の支持点から先 端面までの長さは $30 \mathrm{~mm}$ として用いている。また，レーザ ダイオード光源には中心波長 $670 \mathrm{~nm}$ のオーディオテクニ カ社製 SU-32E を，PSD には 320〜1100nm の感度波長を もつ浜松ホトニクス製 S3932 をそれぞれ使用した。

精密移動台を移動させて光ファイバ触針が試料表面をな
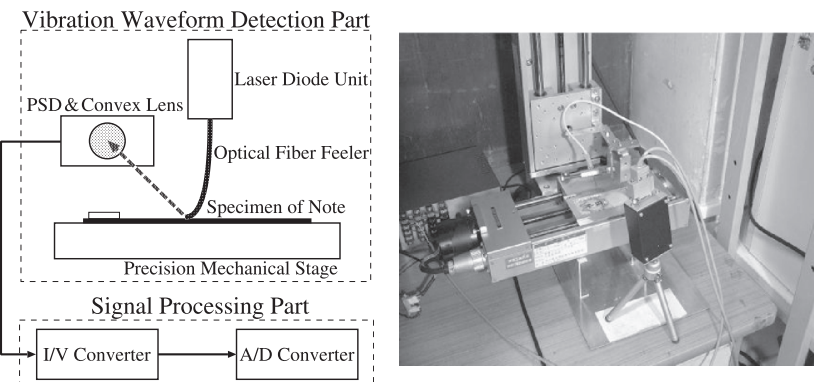

Fig. 1. Configuration and photograph of the optical fiber feeler scanning system

Table 1. Specifications of the optical fiber (CK-40)

\begin{tabular}{|c||c|}
\hline Item & Specification \\
\hline \hline Diameter & $1.0 \mathrm{~mm}$ \\
\hline Diameter of core & $0.980 \mathrm{~mm}$ \\
\hline Young's modulus of core & $2.94 \mathrm{GPa}$ \\
\hline
\end{tabular}

ぞるとき，触針先端からの射出光が PSD 受光面上に結像 する位置を観測する構成であり, 電流-電圧変換回路および 16bit の AD コンバータを介して PSD 出力電流を PCへ収 録し，変位への変換処理を施すことで走査波形が得られる。 精密移動台には中央精機製の PS-120E，AD コンバータに はコンテック製の AD16-16U(PCI)EH を使用した。走査 波形観測時の移動台速度は $2.0 \mathrm{~mm} / \mathrm{s}$, データサンプリング レートは $1 \mathrm{kHz}$ とし，500 点 $/ \mathrm{mm}$ で収録を行う。

$\langle 2 \cdot 2\rangle$ 直接光・反射光による等価結像点 光ファイバ 触針走査装置では，触針に対し PSD を意図的に垂直より傾 けて配置してある。この結果，触針先端の射出光成分が受 光面に直接結像した「直接光」と, 試料表面における射出 光の乱反射成分が結像した「反射光」が同時に観測される。

直接光と反射光による各結像点位置は触針先端の水平方 向変位に応じて一緒に移動するが，反射光による結像点の 輝度については試料表面の反射率に応じて変化が起こる。 Fig. 2 に示すように，白色領域では反射光も PSD 上に結像 するが，黒色領域では光線のほとんどが吸収されて直接光 のみが結像する。

これら 2 つの成分が重畳される結果, PSD 受光面での等 価結像点位置は，触針の水平方向変位だけではなく試料表 面の反射率変化によっても移動することになる。すなわち， 走査波形として獲得される等価結像点位置は，PSDの性質 よりそれらの輝度を重みとする荷重平均として表現される。

\section{$\langle 2 \cdot 3\rangle$ 走査波形から獲得される試料の表面性状情報}

$\langle\mathbf{2} \cdot \mathbf{3} \cdot \mathbf{1}\rangle$ 直接光に基づく凹凸・摩擦係数の獲得 触 針先端の水平方向の振動変位が観測できる直接光による結 像点位置変化には，凹凸や摩擦係数などの表面性状を発生 要因とするスティックスリップ成分 ${ }^{(7)}$ が現れる。

スティックスリップ現象は Fig.3 左図に示すような力学 モデルで説明できる。移動台を矢印方向に動かすとき，初
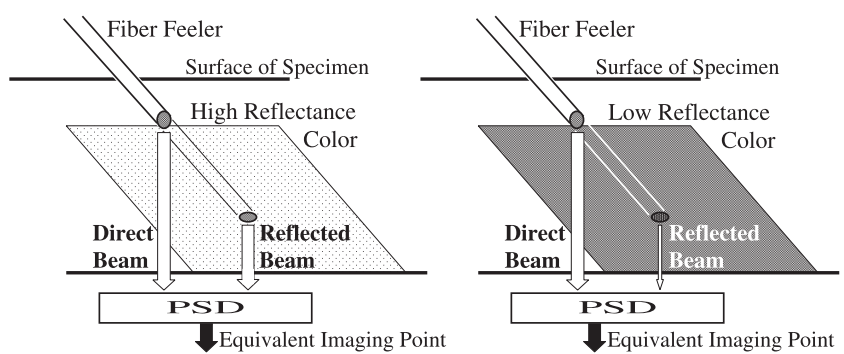

Fig. 2. Schematic view of the equivalent imaging point derived from the direct and reflected beam
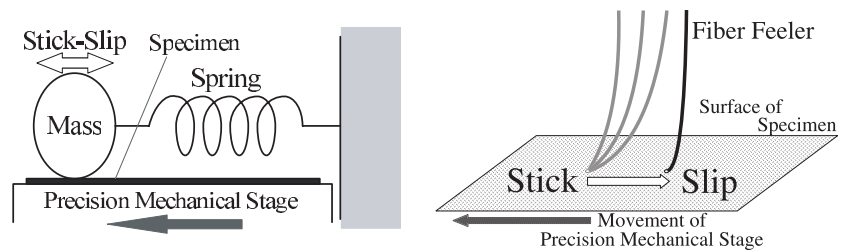

Fig. 3. Dynamical model and schematic view of the stick-slip phenomenon 
めは質点と試料表面間の最大静止摩擦力>バネ力であるた め, 質点は左に移動 (スティック)する。その後，バネ力> 摩擦力となると質点は右に引戻 (スリップ) され，この動作 の繰り返しにより振動的な変位を生じる。光ファイバ触針 走査装置では触針が質点とバネの役割を果たし, Fig.3 右 図のように試料表面の凹凸への引っ掛かりや摩擦力変化に よって触針先端が試料表面に対し付着と滑りを繰り返す一 連の動作がスティックスリップ現象であり，触針先端の振 動変位がノコギリ状の走査波形として観測される。

Fig.4 は，触針に適当な押付力†が与えられた条件下で， 背景が一様な凹凸・平滑区間に対して得られた走査波形の 例であり，紙面の凹凸状態によってスティックスリップ成 分の出現状況が大きく変化するようすを確認できる。紙幣 表面におけるステイックスリップ成分の出現頻度や振幅は, 凹版印刷による微小な凹凸や粗さあるいは紙面や印刷によ る摩擦係数変化などの表面性状と相関をもって変化するも のと予測できる。

\section{$\langle\mathbf{2} \cdot \mathbf{3} \cdot \mathbf{2}\rangle$ 反射光に基づく印刷模様の獲得試料表面} における反射率の変化が観測できる反射光による結像点の 輝度変化には, 濃淡など印刷模様の表面性状を発生要因と する成分が現れる。

Fig.5 は平滑な白 $\rightarrow$ 黒 $\rightarrow$ 白の印刷模様をもつ区間に対 する走査波形の例である。黒色の区間では直接光による等 価結像点位置が観測されているが，白色の区間では反射光 の影響を受けて等価結像点位置が移動し，印刷模様に対応 する波形成分が見掛け上で観測されている。紙幣表面でも， スティックスリップ成分に比較して低周波数成分で，印刷 模様という表面性状と相関をもった波形成分が観測される ものと予測できる。

\section{〈2・4〉 紙幣表面による走査波形の性質}

$\langle 2 \cdot 4 \cdot 1\rangle$ 紙幣判別のための走査ライン選定

紙幣の

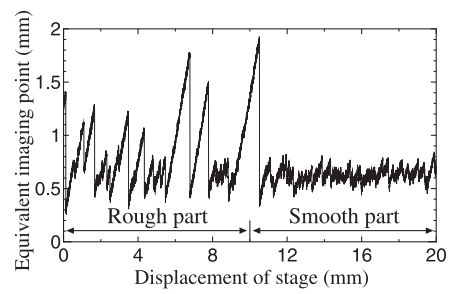

Fig. 4. Measured vibration waveform derived from the rough and smooth surface

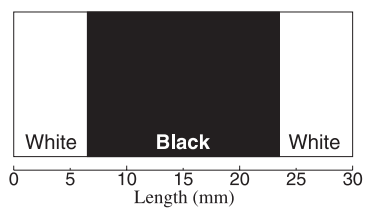

Print Pattern of Specimen

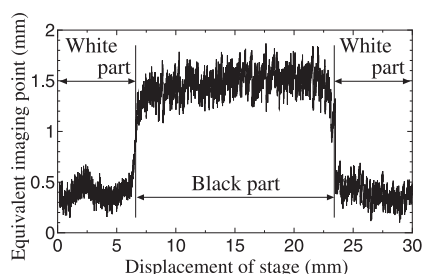

Fig. 5. Measured vibration waveform derived from the black and white print pattern

†本走査波形観測時の触針押付力は定量的に評価をしていないが, $く 2 \cdot 4 \cdot 2$ 節で後述する観測条件とほぼ同一であったと考えられる。
判別において金種判別が必須であることを踏まえると，触 針走査は各金種に固有な性状をもつ領域へ行う必要がある。 また真贋情報判別には，真券のみに固有な性状である凹版 印刷領域に対する走査が有効と考えられる。このような要 件を同時に満たす領域はいくつかあるが，本研究では印刷 インクの凹凸によって顕著に相違が現れ易いと推測される 額面の凹版印刷部分を走査領域として選定した。

Fig.6 には，弐千円札を例に触針先端の走査ライン (矢印 線) と, 触針式表面形状測定器 ((株) ミツトヨ SV-624)に てその走査ライン上の凹版印刷による凹凸情報を $40 \mu \mathrm{m}$ 間 隔で測定した結果を示す。「武千円」の文字上に該当する区 間には，深凹版印刷によるインク盛り上がり量に一致した $20 \mu \mathrm{m}$ 程の微細な凹凸の存在が確認できる。

$\langle\mathbf{2} \cdot \mathbf{4} \cdot \mathbf{2}\rangle$ 真券と贋券による走査波形の比較 国内の贋 券の多くは凹版印刷の施されていない稚拙なものである ${ }^{(1)}$ という状況も踏まえ, 真券の一部をスキャナで読み取り, 上 質紙にプリンタで印刷した武千円札を贋券試料として用意 した。従来の透過光量に基づく方法 (8) では，光線を照射し ながら紙幣を移動させることで得られる走査ライン上の光 透過量の変化に応じて印刷模様が判別されるため, この夕 イプの贋券に対する真贋判別は難しいとされている。

試料紙幣と光ファイバ触針は，Fig.7 に側面図を示すよ うに配置して走査波形を観測した。触針先端の押付力はス ティックスリップ成分の大きさや発生頻度と関係してくる が，触針を片持梁でモデル化した解析に基づけば，このと きの押付力はおよそ $7.2 \times 10^{-2} \mathrm{~N}$ と計算される。

Fig.8 は真券による走査波形とその凹版印刷区間の拡大 図を，Fig.9 は同一条件の贋券による走査波形を示した結 果であり，これまで同様に横軸が移動台移動距離，縦軸が PSD の等価結像点位置を表している。

Fig.6 と照らし合わせると, 低周波数成分は印刷模様と 相関をもち，反射率という観点からは印刷模様が同一であ る両試料では，その軌跡がほぼ一致する。これは低周波数 成分にさえ着目すれば金種 (=印刷模様)に関する情報が獲
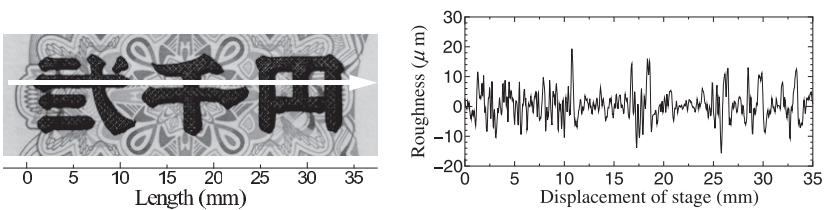

Fig. 6. Scanning line of a 2,000Yen note on the intaglio prints and its roughness data

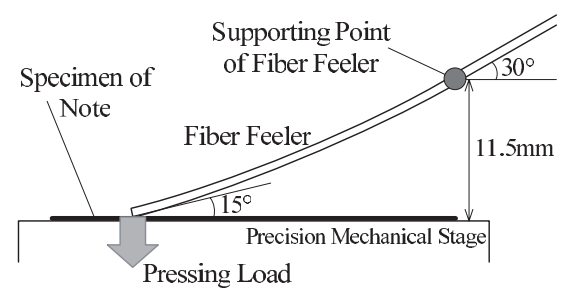

Fig. 7. Side view of an alignment between the optical-fiber feeler and the specimen of notes 

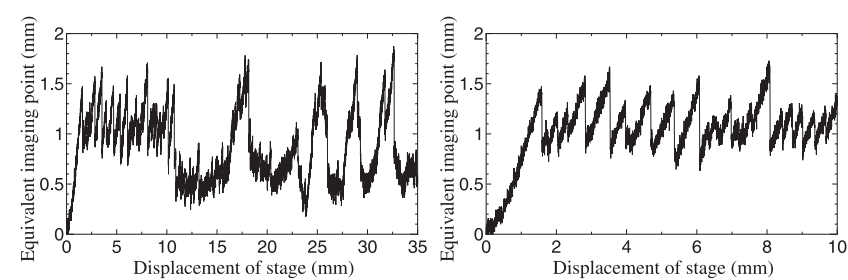

Fig. 8. Measured waveform for the genuine note (rightside; enlarged view of the intaglio print part)
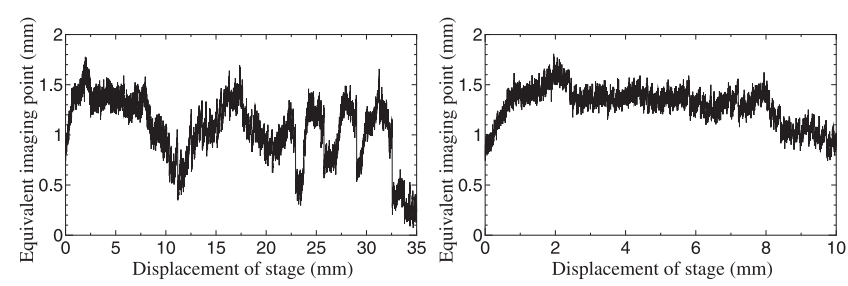

Fig. 9. Measured waveform for the counterfeit note (right-side; enlarged view of the intaglio print part)

得可能であり，それが紙幣の真贋には依らないことを示し た結果といえる。一方，真券の凹版印刷区間にはスティック スリップ成分が観測されているのに対し，凹凸がほとんど 存在しない贋券には観測されていない。すなわち, スティッ クスリップ成分の出現状況が凹版印刷の微小な凹凸の存在 と直接的な相関をもっており，その点に着目すれば真贋に 関する情報が獲得可能であると考えられる。

\section{3. 低周波数成分に着目した金種判別}

$\langle\mathbf{3 \cdot 1}\rangle$ 低周波数成分の抽出 走査波形に対して移動 平均抢上び直流成分除去処理を施し，低周波数成分のみを 抽出する。Fig.10 は，武千円札の官封券 (新券)の走査波形 に対して移動平均点数を 500 点として処理を施した結果で あり, Fig.6 と比較すれば印刷模様と強い相関をもつ波形 成分が抽出されていることがわかる。

印刷模様から金種判別を実現する方法には幾つかのアプ ローチを考え得るが，本研究では印刷の白，黒あるいは黒 一白の切替点の変位情報を利用することとした。Fig.10に 示すように，抽出波形のゼロクロス点から印刷色切替点に 関する情報が推定でき，その交点における移動台の変位を $D_{1}, D_{2}, \cdots$ と扔いて判別処理に利用する。

$\langle\mathbf{3} \cdot \mathbf{2}\rangle$ 指標值を導入した金種判別の実現金種ごと に印刷色の切替変位を記録したデータベース $D_{l}^{*}(* は$ 各金 種を表すインデックス) を事前に用意し，走査波形から推定 した $D_{l}$ との相違度 $E_{*} を ，$ 式 (1) にしたがって算出する。

$$
E_{*}=\frac{1}{M} \sum_{k=1}^{M}\left(D_{k}^{*}-D_{k}\right)^{2}
$$

ここで $M$ は検出されたゼロクロス点の総数である。

各金種のデータベース拉よび走査波形を用意し，相違度 を算出した結果を Table 2 にまとめる。表の横方向には試 料金種を，縦方向には各金種の走査波形に対する相違度を 示してある。全金種に関して, 自金種データベースとの相

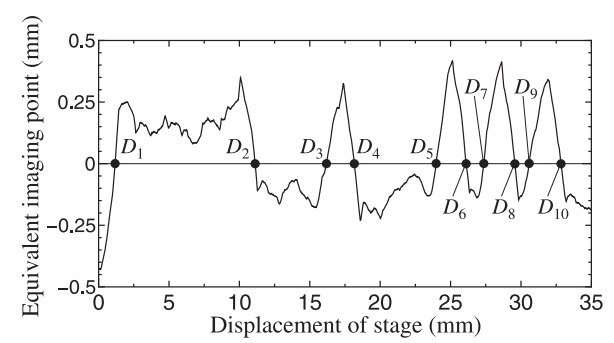

Fig. 10. Extracted low-frequency component from measured waveform of a 2,000Yen note

Table 2. Index $E_{*}$ for each denomination of notes

\begin{tabular}{|l||c|c|c|c|}
\hline & 1,000 yen & 2,000 yen & 5,000 yen & 10,000 yen \\
\hline \hline$E_{1000}$ & 2.4 & 14.9 & 15.2 & 21.2 \\
\hline$E_{2000}$ & 29.8 & 4.7 & 23.1 & 19.9 \\
\hline$E_{5000}$ & 27.9 & 20.8 & 1.6 & 22.2 \\
\hline$E_{10000}$ & 32.4 & 24.0 & 33.8 & 5.2 \\
\hline
\end{tabular}

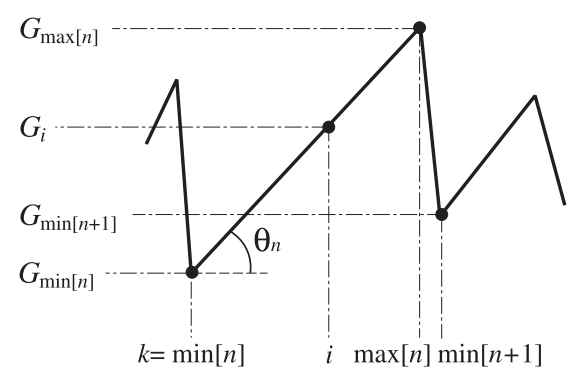

Fig. 11. Model of the stick-slip component

違度は他金種データベースとの相違度に比較して一桁程の 違いが出ることを確認し, 提案する相違度 $E_{*}$ に対して単 純な閾值処理を適用することで金種判別が実現できる。

\section{4. スティックスリップ成分に着目した真贋判別}

$\langle\mathbf{4} \cdot \mathbf{1}\rangle$ スティックスリップ成分の特徴評価スティッ クスリップ成分を Fig.11に示すように極小值 $G_{\min [n]}$ と $G_{\min [n+1]}$ および極大值 $G_{\max [n]}$ を 1 組とみなしてモデ ル化し, 走査波形からその成分を抽出する。ここで $n$ は $1 \leq n \leq N$ であり， $N$ は抽出される成分の総数を表す。

その発生原理からスティック時の触針先端の変位は移動 台の移動距離と一致し, Fig. 11 に示した $\theta_{n}$ は $45 \mathrm{deg}$ をと ることが大きな特徵である。そこで，抽出成分の波形形状 的特徵の評価には, スティックの傾きおよび波形振幅值に 関する特徵パラメー夕を導入する。まず $\theta_{n}$ を式 $(2)$ により 算出し，スティックの傾きパラメータとする。

$$
\theta_{n}=\tan ^{-1}\left\{\frac{G_{\max [n]}-G_{\min [n]}}{\max [n]-\min [n]}\right\}
$$

また波形振幅パラメータについてはスティック中の触針 変位量を利用し， $L_{n}$ として式 $(3)$ により算出する。

$$
L_{n}=G_{\max [n]}-G_{\min [n]}
$$

$L_{n}$ はスリップ現象に打ける触針変位量を利用して算出する ことも可能であるが，スリップ途中に新たな凹凸への引っ 
掛かりが生じてしまう場合があるなど，触針の振動変位に 不安定な要素も多い。本研究では，より正確性の高い特徵 評価を実現するため, 余計な触針の振動変位が生じないス ティック現象に着目した。

$\langle 4 \cdot 2\rangle$ 真券と贋券による特徵パラメータの比較 真 券およびソリッドインクプリンタとレーザプリンタで印刷 した 2 種類の贋券による計 3 種類の走査波形に対し，観測 ノイズによる高周波数成分を除去した後にステイックスリッ プ成分を抽出し, 特徵パラメータを算出した。真贋別に $L_{n}$ と $\theta_{n}$ の関係をプロットした結果を Fig.12 に示す。

真券の走査波形に対しては，特に $L_{n}$ が大きな領域で $\theta_{n}=45 \mathrm{deg}$ 近傍での分布が得られており，モデル化による 成分抽出の妥当性と特徵パラメータ值の有効性が同時に示 された結果といえる。 $L_{n}$ が小さな領域では $\theta_{n}$ が小さくな る傾向にあるが，これは除去し切れていない観測ノイズ成 分などの影響による。一方，贋券では真券同様に $L_{n}$ が小 さな領域では $\theta_{n}$ が小さくなる傾向を確認すると同時に，ス テイックスリップが発生しないという贋券の走査波形の特 徵が正確に得られ， $L_{n}$ の大きな領域では $\theta_{n}=45 \mathrm{deg}$ 近傍 にほとんど抽出成分が存在しないという結果となった。

これらの結果から，モデル化を利用したスティックスリッ プ成分の抽出法およびその形状に着目した特徵パラメータ による評価法の有効性が実験的に示された。

〈4・3〉 性状情報の複合的利用による信頼性向上【 版印刷の凹凸はスティックスリップの発生要因となるが，例 えば粗い紙面であってもスティックスリップは発生し，そ のような紙面をもつ贋券では真贋判別を誤る可能性がある。 そこで金種 (=印刷模様) に関する情報を複合的に利用し, 真贋判別の信頼性を向上させる方法を検討する。

Fig.13 は，金種判別に利用した $D^{*}$ とその金種情報を基
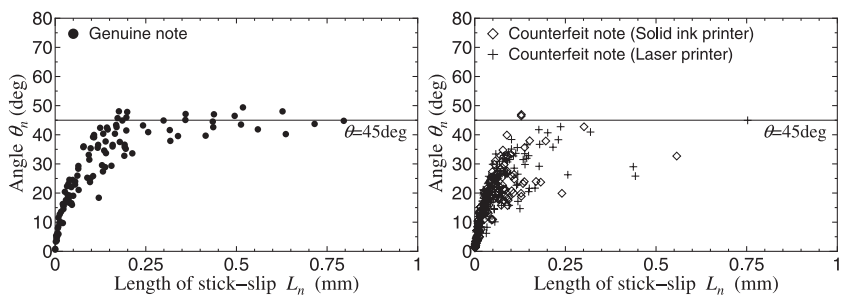

Fig. 12. Relationship between $L_{n}$ and $\theta_{n}$ for the extracted stick-slip component (left-side; for the genuine note, right-side; for the counterfeit note)
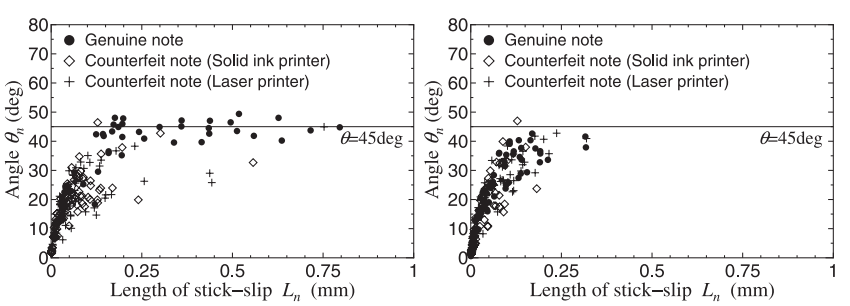

Fig. 13. Relationship between $L_{n}$ and $\theta_{n}$ for the extracted stick-slip component (left-side; for the intaglio print part, right-side; for the independent of the intaglio print part)
に各種紙幣の走査波形を凹版印刷区間および無印刷区間に 区分化し，各々の区間に対してスティックスリップ成分抽 出処理を適用した際の $L_{n}$ と $\theta_{n}$ の関係を示している。真券 での印刷区間における抽出成分の多くがスティックスリッ プであり，無印刷区間の分布との差は顕著であるのに対し， 贋券では無印刷区間との差はそれほど大きくない。

すなわち，印刷区間と本来凹凸が少ない無印刷区間での スティックスリップ出現状況を組み合わせれば，その差異 を評価することによって印刷区間におけるスティックスリッ プの発生要因となった表面性状を推定することができ，真 贋判別性能の向上を図ることが可能である。

$\langle 4 \cdot 4\rangle$ 指標值を導入した真贋判別の実現

スティック スリップ成分の出現状況をその傾きと振幅值から評価する ために，大きな特徵である $\theta_{n}=45 \mathrm{deg}$ が得られることを利 用した指標值として， $\rho$ を式 (4)によって定義する。

$$
\rho=1-\left[\prod_{k=1}^{\tilde{N}}\left\{1-e^{-\frac{\left(\theta_{k}-45\right)^{2}}{2 \sigma^{2}}}\right\} 10^{-L_{k}}\right]^{1 / \tilde{N}} .
$$

ここで $\tilde{N}$ は評価対象となる各印刷区間あるいは無印刷区間 における抽出成分数である。 $45 \mathrm{deg}$ を平均值とした $\theta_{n} に$ 関する正規分布項と, $-L_{n}$ を指数とするべき乗項を基に構 成している。 $\theta_{n}=45 \mathrm{deg} に$ 近くかつ $L_{n}$ が大きい成分ほど 影響力は強く $\rho$ 值は 1 に近づくが，逆に $\theta_{n}=45 \mathrm{deg}$ から外 れるかあるいは $L_{n}$ が小さな成分は影響力が弱く, 抽出成 分が存在していても $\rho$ 值は 0 からほとんど変動しない。

各 24 枚の官封券および流通券の走査波形に対し，式 (4) 中の $\sigma=3.0 \mathrm{deg}$ として得られた $\rho$ 值の平均值 $\bar{\rho}$ とその標準 偏差 $\sigma_{\rho}$ をTable 3 にまとめる。大振幅のスティックスリッ プ成分が多数存在する真券の凹版印刷区間では, 官封券 · 流通券によらず相対的に $\bar{\rho}$ 值は大きく, 無印刷区間の值と は 2 倍以上の違いがある。一方, Table 4 にまとめた贋券 に対する結果では，凹凸が存在しないことで印刷区間の $\bar{\rho}$ 值は真券に比較して大幅に小さくなる傾向を示し, 紙幣の 真贋に因らず值が小さい無印刷区間の $\bar{\rho}$ 值と一致する。

以上の結果より，印刷区間でのみ $\rho$ 值の大きい試料を閾 值処理で選別すれば，真贋判別が達成可能である。

$\langle 4 \cdot 5\rangle$ 傷み度合判別への応用可能性傷み度合判別で は，再流通させた際に贋券と区別がつかなくなる恐れのあ

Table 3. Indexes $\bar{\rho}$ and $\sigma_{\rho}$ for each type of the genuine notes

\begin{tabular}{|c||c|c||c|c|}
\hline \multirow{2}{*}{ Index } & \multicolumn{2}{c||}{ New notes } & \multicolumn{2}{c|}{ Circulated notes } \\
\cline { 2 - 5 } & Print part & Non-print part & Print part & Non-print part \\
\hline \hline $\bar{\rho}$ & 0.768 & 0.300 & 0.648 & 0.277 \\
\hline$\sigma_{\rho}$ & 0.114 & 0.093 & 0.106 & 0.090 \\
\hline
\end{tabular}

Table 4 . Indexes $\bar{\rho}$ and $\sigma_{\rho}$ for each type of the counterfeit notes

\begin{tabular}{|c||c|c|}
\hline Index & Print part & Non-print part \\
\hline \hline $\bar{\rho}$ & 0.192 & 0.152 \\
\hline$\sigma_{\rho}$ & 0.040 & 0.035 \\
\hline
\end{tabular}




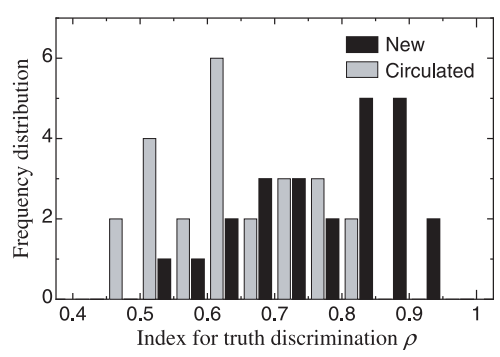

Fig. 14. Histogram of index $\rho$ for the intaglio print part of new and circulated notes in the market

る污れた券やよれた券などを取り除くことが目的となる。

Fig.14はく 4 •4 節における検討の際に得られた真券の凹 版印刷区間に対する $\rho$ 值の度数分布を示した結果である。 流通による磨耗などで凹版印刷の凹凸が減少し傷みが進行 した流通券では, 官封券に比較して $\rho$ 值が小さな領域へ移 行する傾向が見られた。指標值 $\rho$ は凹版印刷による凹凸度 合を判別するために提案したものではあるが， $\rho$ 值を利用 することにより，従来はあまり考慮されなかった表面の磨 耗度合に基づく傷み度合判別を実現できる可能性は高い。

\section{5. 紙幣判別処理法の実験的検証}

$\langle\mathbf{5} \cdot \mathbf{1}\rangle$ 判別方法の適性比較 提案方法掞よび比較と しての透過光量に基づいた判別方法につき，各種紙幣を対 象とした場合の金種・真贋判別への適性を整理した結果を Table 5 にまとめる。表中の記号は，○は正確な判別が可 能なことを，×は判別が不可能なことを， $\triangle$ は誤判別の可 能性があることをそれぞれ意味している。

金種判別では，真券と模様が一致しない贋券には正しい 判別が期待できず，この点は透過光量に基づく方法でも同 様である。しかしながら真贋判別に拉いては，模様が一致 しない紙幣に対しては，提案方法では最適な印刷・無印刷 区間の選択が難しく誤判別の可能性も残るが，模様が一致 していれば問題無く判別可能である。これは透過光量に基 づく方法とは正反対の特性であり，模様が一致していて濃 淡情報からは判別が難しいとされる贋券に対し正確な真贋 判別が行えることは，提案方法の大きな優位点である。

$\langle\mathbf{5} \cdot \mathbf{2}\rangle$ 紙幣判別処理法の構築 提案した判別方法の 適性を考慮に入れ，各方法によって獲得される性状情報を 複合的に利用しながら効果的にその順序・判別基準を組み 合わせることにより，信頼性の向上を図った判別法を構築 することが可能である。現在国内に流通する紙幣の場合を 一例として，そのフローチャートを Fig.15に示す。

まず金種判別を先に実施して真贋を問わず 4 つの金種に 分類すると共に，全ての金種に対して相違度が大きな試料 についてはこの時点で贋券と判別する。真贋より先に金種 を判別する理由は，真贋判別における印刷区間選択を金種 ごとに最適化するためであり，真贋判別に際して金種情報 を複合的に利用することで誤判別を減少させ，信頼性を高 めることがその狙いである。
Table 5. Propriety of a proposed method and the transmitting light method for various type of notes

\begin{tabular}{|c|c|c|c|c|}
\hline \multirow{2}{*}{ Types of note } & \multicolumn{2}{|c|}{ Proposed method } & \multicolumn{2}{|c|}{ Transmitted light method } \\
\hline & Denomination & Truth & Denomination & \begin{tabular}{l|l|} 
n & Truth \\
\end{tabular} \\
\hline Genuine & $\bigcirc$ & $\bigcirc$ & $\bigcirc$ & $\bigcirc$ \\
\hline Type $1 \%$ & 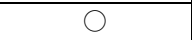 & $\bigcirc$ & $\bigcirc$ & $x$ \\
\hline Type $2^{※}$ & $\bigcirc$ & $\bigcirc$ & $\bigcirc$ & $x$ \\
\hline Type $3 *$ & $x$ & $\triangle$ & $x$ & $\bigcirc$ \\
\hline Type 4 * & $\times$ & $\triangle$ & $x$ & $\mathrm{O}$ \\
\hline${ }^{*}$ Counterfeit type & \multicolumn{3}{|c|}{ Print pattern } & Paper surface \\
\hline Type 1 & \multirow{2}{*}{\multicolumn{3}{|c|}{ Correspond to genuine note }} & Smooth \\
\hline Type 2 & \multicolumn{2}{|c|}{ Correspond to genuine note } & & Rough \\
\hline Type 3 & \multicolumn{3}{|c|}{ Not correspond to genuine note } & Smooth \\
\hline Type 4 & \multicolumn{3}{|c|}{ Not correspond to genuine note } & Rough \\
\hline
\end{tabular}

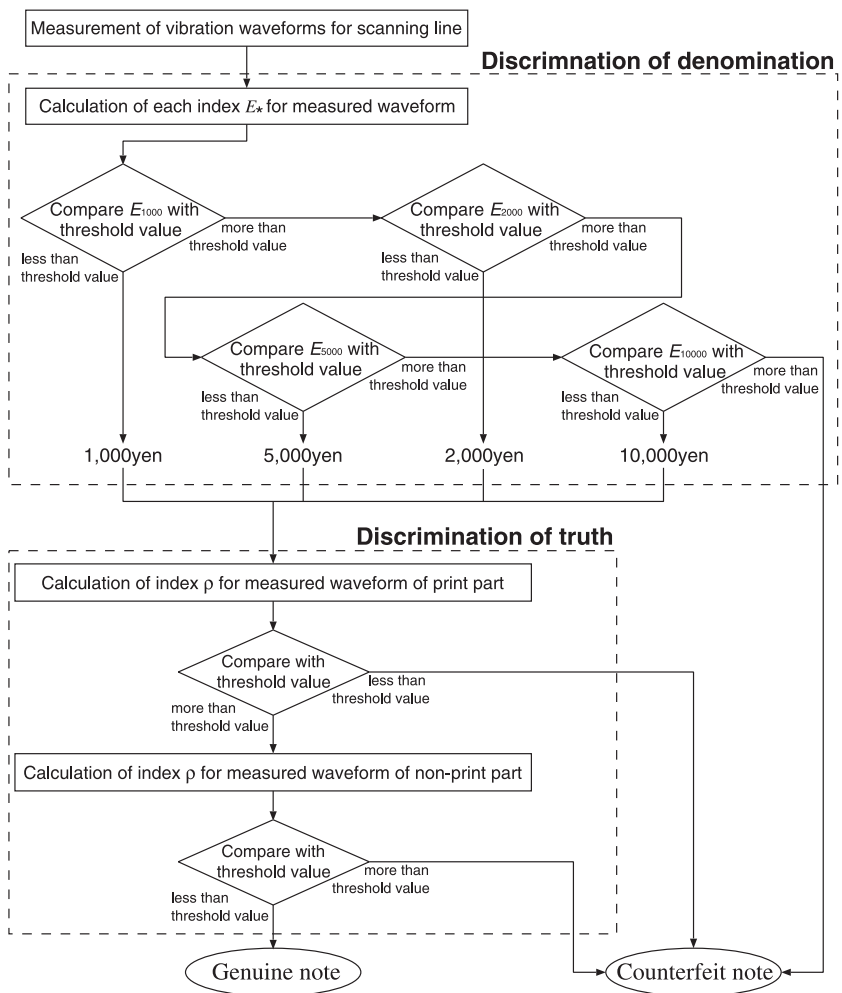

Fig. 15. Flow of discrimination process for the circulated notes in the market

次段の真贋判別では，走査波形中の凹版印刷区間㧍よび 無印刷区間に対してそれぞれ指標值を算出し，双方が間値 条件を同時に満たした場合にのみ真券と判別される。

$\langle\mathbf{5} \cdot \mathbf{3}\rangle$ 実紙幣への適用結果 ATM や店頭で入手した 官封券・流通券 (千，武千，五千，壱万円券) 拉よび贋券の 計 66 枚から獲得した走査波形に判別方法を適用し，その 性能を検証した。なおく $3 \cdot 2$ 節抢よび $4 \cdot 4$ 節での検討結果 より，金種判別の相違度 $E_{*}$ に関する闇值は 10.0 , 真贋判 別の指標値 $\rho$ の闇值はその分散值を踏まえ 0.46 とした。

結果は金種判別・真贋判別ともに $100 \%$ の判別率が達成 されることを示し，特に透過光量に基づく方法では難しい とされる贋券試料に対し $100 \%$ の真贋判別率が達成された ことは，提案方法の優位性が明らかになった結果といえる。 一方, 真贋判別に際して指標值 $\rho$ が閾值近傍をとる試料も 
見受けられたが，傷みの進行状況に鑑みても得られた指標 值は妥当であり，傷み度合判別を追加すれば指標值 $\rho$ から その順位付けさえも可能であると推察される。

以上の結果から，金種・真贋判別法およびそれらを組み 合わせた紙幣判別処理法の有効性が確認された。

\section{6. 結 言}

本論文では，紙幣の真贋・金種判別を実現するために，紙 幣に固有かつ特徽的な表面性状に着目した判別方法を新た に提案した。提案方法では，触針で紙幣表面をなぞったとき に生じる特徴的な振動変位波形から，凹版印刷による凹凹 あるいは印刷模様と相関を持つ波形成分が抽出でき，そこ から獲得される性状情報を複合的に利用して判別を試みた。

金種判別においては，走査波形の低周波数成分が印刷模 様情報と相関を持つことを明らかにし，観測された走査波形 の低周波数成分を基に推定した印刷模様情報と各金種デー タベースとの相違度を指標化し，その判別を実現した。

真贋判別においては，凹版印刷による凹凸・摩擦係数变 化を発生要因とするスティックスリップ成分に着目し，ス テイック中の触針先端の変位が移動台の移動距離に一致す る特徴を利用して，その成分の出現状況を評価するための 指標值を新たに提案した。加えて，凹版印刷の有無に依存 して成分の出現状況が大きく異なるという性質を利用して 判別性能を向上させ，信頼性を高めることに成功した。

さらに，獲得された性状情報を複合的に組み合わせて利 用する紙幣判別処理法を構築し，試料紙幣への適用を試み たところ，金種判別・真贋判別ともに $100 \%$ の判別率が達 成されることを確認し，提案方法の有効性を示した。

一方で，今回は透過光量に基づく方法での真贋判別が難 しいとされる贋券試料を用意したが，紙面の正確な凹凸情 報との比較によって光ファイバ触針による表面性状評価が 有効となる範囲を確認し，その他夕イプの偽券に対する提 案方法の適用範囲を明らかにする必要がある。また, 現在 の触針走査速度は必ずしも十分ではないため，触針の剛性 や押付圧なども考慮に入れ，高速走査を実現するための検 討も必要である。

(平成 19 年 2 月 26 日受付，平成 19 年 8 月 27 日再受付)

\section{文献}

（1）「2005/1/18 読売新聞・社説：偽札事件 一刻も早く根絶すべき犯罪 だ」, 読売新聞社 (2005)

（2）「2005/4/6 読売新聞・偽札判別ツール」，読売新聞社 (2005)
（3）「2005/12/7 読売新聞・瞬時に偽札判別「マジックシート」」，読売 新聞社 (2005)

(4) Y. Akao, K. Kobayashi, S. Sugawara, and Y. Seki: "Discrimination of inkjet-printed counterfeits by spur marks and feature extraction by spatial frequency analysis", Proc. SPIE, Vol.4677, pp.129-137 (2002)

(5)「2006/6/15 朝日新聞」, 朝日新聞社 (2006)

(6) M. Tanaka, L. Cao, S. Ohyama, and A. Kobayashi: "Evaluation and Data Analysis on the Scanning Method using Optical Fiber Feeler to Measure Cloth Handvalue", The Papers of Technical Meeting on Sensors and Micromachines, pp.13-18 (1997) (in Japanese)

田中正行・曹 麗・大山真司・小林 涁：「光ファイバ触針による布 の手触り感計測のための走査方式の検討とデー夕解析」, 電学セン サ・マイクロマシン部門総合研資, pp.13-18 (1997)

(7) M. Tanaka, L. Cao, S. Ohyama, and A. Kobayashi: "Discrimination of Cloth Materials with Scanning Optical Fiber Feeler", SICE Trans., Vol.36, No.2, pp.151-158 (2000) (in Japanese)

田中正行·曹 麗・大山真司・小林 樹:「光ファイバ触針の走査によ る布の識別」，計測自動制御学会論文集，36-2，pp.151-158 (2000)

（8）木寺謹一・橋本道明 - 橋本正昭 - 大野 稜：公開特許「紙幣真偽判別 方式」, 特許公報昭 58-42913 (1983)

高 山 潤 也 (非会員) 1998 年, 東京工業大学大学院修士課

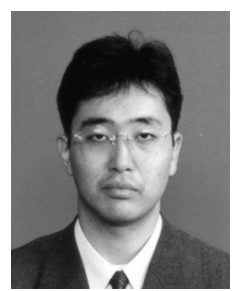
程修了。同年日産自動車 (株) 入社。2000 年, 東 京工業大学大学院理工学研究科機械制御システム 専攻助手, 現在, 同学大学院理工学研究科助教。 高度能動計測系としての信号場の理論とその応用 などの研究に従事。

大 山 真 司 (正員) 1984 年, 東京工業大学大学院修士課程

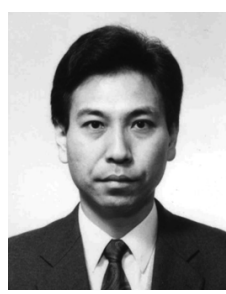
修了。同年 (株) 日立製作所日立研究所入社。90 年, 東京工業大学工学部助手, 現在, 同学大学院 理工学研究科准教授。計測工学, 計測システム構 成論等の研究, 教育に従事。計測自動制御学会, 電子情報通信学会の会員 (博士 (工学 $)$ )。

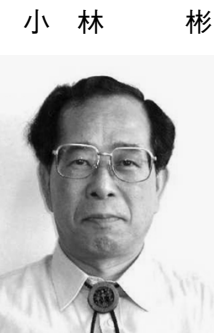

（正員） 1969 年, 東京工業大学大学院博士課程修 了。同年東京工業大学助手。 87 年同教授, 2005 年退官。現在, 大学評価·学位授与機構客員教授。 計測用空間フィル夕，感覚計測，解領域法による 信号処理, 信号場, 高 SN 比計測法などの研究に 従事 (工学博士)。 